Вісник Львівського університету. Серія психологічні науки. 2018. Випуск 3. С. 148-151

Visnyk of the Lviv University. Series Psychological science. Issue 3. P. 148-151

UDC 159.9.072.42

DOI https://doi.org/10.30970/2522-1876-2018-3-18

\title{
PSYCHOLOGICAL PECULIARITIES OF STUDENTS WITH DIFFERENT LEVELS OF ACADEMIC ABSENTEEISM
}

\author{
Maria-Olha Sopeliuk \\ Ivan Franko National University of Lviv, \\ 1, Universytetska Str., Lviv, Ukraine, 79000, \\ e-mail:solomaha04@gmail.com
}

\begin{abstract}
The article deals with the analysis of academic absenteeism of students. In the empirical research, it was involved 121 respondents and used a complex of methods: own questionnaire, "Big five" of R. MacCrae and P.Costa, methods of T.I. Ilina "Study of students' motivation of in HEI", Yu.Z. Gilbukh questionnaire of personal maturity, "Assessment of team psychic atmosphere" of A.F. Fidler and mathematical-statistical research methods. The results show that $46 \%$ of respondents have an average level of academic absenteeism, $29 \%$ - high level, and $25 \%$ - low level. It was found out that students with a low level of academic absenteeism are most motivated for obtaining knowledge and students with a high level of academic absenteeism have are oriented to mastering a profession and obtaining a diploma. The results of frequency response analysis indicate that there are differences due to a study year, programme and tuition payment. In particular, first-year students mainly have a low level, freshmen and juniors have an average level, and third-year students have a high level of academic absenteeism. Students with a low and average level of academic absenteeism got scholarship allowance and students with a high level - pay tuition. With regard to payment for education students with a low and average level of academic absenteeism are paid by parents, and students with a high level of academic absenteeism pay tuition on their own. Psychological profiles of students were created on the basis of the research. Students with a low level of academic absenteeism are characterized by carefulness, neatness, expressiveness and flexibility, that is, they are able to adapt quickly and adjust to any changes, do everything clearly, correctly and in accordance with the norms. Students with an average level of academic absenteeism are characterized by rigidity - they don't tend to adapt quickly to shifts. Students with a high level of academic absenteeism are characterized by independence, autonomy, low level of volitional qualities, low level of self-control, responsibility and persistence, that is, the respondents are quite impulsive (perhaps this contributes to a high level of absenteeism). In addition, students with a high level of absenteeism mostly work that also significantly influences the attendance of a higher education institution.

Key words: absenteeism, academic absenteeism, motives of training, psychological climate.
\end{abstract}

Currently, there is a tendency to increase students' academic absenteeism due to the availability of higher education, online books, magazines (journals), lectures, seminars and quick access to any information. Academic absenteeism has been researched by R. Shmidt, D. Marburger, J. McGregor, C. Shell-Rani, A. Ginsburg, J. Chang, H. Chang and other. A study by Alan Ginsburg, Phyllis Jordan and Hedy Chang conducted in August 2014 shows that students with higher absenteeism rates have lower scores on national standardized tests [27]. It reinforces a growing body of research confirming the connection between school attendance and students' achievements.

Researches pointing out, that students from families with low income are more likely to miss their lectures, then other student as they meet with material difficulties and they have to work at the same time to help their family or to be able to afford their studies. Researches in area of academy absenteeism mainly was carried by foreign scholars and they quote that - the higher is absenteeism means the lower knowledge and studies of the students. But there is still not enough learned about psychological characteristics of students with different levels of absenteeism. So the problem that came out in the article is to identify psychological characteristics of the students, and what inducing them to absenteeism.

(C) Maria-Olha Sopeliuk, 2018 
Academic absenteeism is students' non-presence in classes without valid reason. There is a number of factors associated with poor school attendance, including: personal and family problems, illness, sudden household tasks $[15 ; 17]$. There are such basic methods to combat academic absenteeism as "carrot and stick" (reward and punishment), conversation with the student, formal approach and strict control [6]. Batih suggesting imposition of administrative or financial fees on the students. Gingerbread characterised by establishing flexible schedules, providing additional material rewards, prize for the work etc. "Chat with the student" it's a method of giving student their feedback and to understand them better with their demotivation and together come to the eliminate outcome. So one on one discussions are very effective in practice. Formal approach requires from students proving any supporting documents such as note from the doctor, release from release from lecture, explanation etc. Strict control - is characterised by total control over students during their lectures, meaning the guys need to sit quietly and listen to the teacher, without any distractions or doing other things that they shouldn't.

On the basis of theoretical analysis of literature, an original theoretical table of the main indicators of academic absenteeism has been compiled (see Table 1).

The theoretical model of the peculiarities of students that are or are not predisposed to academic absenteeism

\begin{tabular}{|c|c|}
\hline $\begin{array}{c}\text { Predisposition to the high level } \\
\text { of academic absenteeism }\end{array}$ & $\begin{array}{c}\text { Predisposition to the low level } \\
\text { of academic absenteeism }\end{array}$ \\
\hline Low academic achievement & High academic achievement \\
\hline Low social status & High social status \\
\hline Low level of volitional qualities & High level of volitional qualities \\
\hline Females & Males \\
\hline Young people & Older people \\
\hline $\begin{array}{c}\text { Tend to have low social status and to be } \\
\text { unemployed in the future }\end{array}$ & $\begin{array}{c}\text { Tend to be highly successful and professionally } \\
\text { competent in the future }\end{array}$ \\
\hline $\begin{array}{c}\text { Lack of strict control over the university students' } \\
\text { class attendance }\end{array}$ & $\begin{array}{c}\text { Strict control over the university students' class } \\
\text { attendance }\end{array}$ \\
\hline Warm season & Cold season \\
\hline
\end{tabular}

Academic absenteeism includes several key indicators: socio-demographic (gender, age, social status), behavioral (absence from class, occupation with other activities, late attendance) and psychological peculiarities (the level of development of the volitional qualities).

The following methods have been used in the research: original questionnaire, methodology "Studying of the motivation to study in higher education institution" (T.I. Ilyina), Five-Factor Inventory (the NEO Personality Inventory ) by R. McCrae, P. Costa, Personal maturity inventory by Yu.Z. Hilbukh, methodology (questionnaire ) "Evaluation of psychological atmosphere in a team" (A.F. Fiedler), mathematical and statistical methods of research: benchmarking by Sheffey and Wallace, factor analysis, discriminant analysis, psychological profiles of each group of students under research are compiled.

The results of the study have shown that $46 \%$ of the students have a moderate level of academic absenteeism, 29\% have a high level, and 25\% - a low level of academic absenteeism. Therefore, it can be concluded that the moderate attendance prevails among students in higher education institution. The motive for obtaining knowledge prevails in all the students under study, that is a positive result. However, after researching each motive individually, it has been established that the motive for obtaining knowledge is the most common among students with a 
low level of academic absenteeism. The motive for mastering the profession and the motive for obtaining a diploma are the most common among students with a high level of academic absenteeism. Most working students belong to the group of students with the high level of academic absenteeism. Students miss classes because they are already employed.

On the basis of the obtained data, psychological portraits have been compiled, thus, students with a low level of academic absenteeism are first year students mostly that receive state-funded education, they have a motive for learning, that is, they attend classes in order to receive new information, gain knowledge and development (growth). Concerning psychological peculiarities, they are characterized by diligence, cleanliness, expressiveness and flexibility, that is, students are able to adapt quickly to any changes, to do everything accurately, correctly and in accordance with the norms. The students noted that they have excellent academic performance, but objective data to prove this statement has not been found in the research process.

Students with a moderate level of academic absenteeism are mostly fourth year students that receive state-funded education. They are characterized by rigidity, do not adapt quickly to various changes, believe that they attend university as often as an average student, that means they assess their attendance honestly, objectively and frankly, and their answers are sincere.

Students with a high level of academic absenteeism have a motive for obtaining a diploma and a motive for mastering the profession, they study in order to obtain a diploma or to improve their knowledge in the professional field. Usually, such group consists of third- and fourth year students that pay tuition fees by themselves. They are characterized by independence, self-determination, low level of volitional qualities, low self-control, responsibility and persistence. This type of students is quite impulsive and it may contribute to the high level of absenteeism. Furthermore, most students with a high level of absenteeism already work, that also affects significantly the attendance of the university.

Taking into account the results of the study, it can be concluded that the theoretical model has been confirmed only partially, as new motivational and psychological peculiarities of students with different levels of academic absenteeism have been discovered (see Table 2).

\section{The empirical model of the peculiarities of students with different levels of academic absenteeism}

\begin{tabular}{|c|c|}
\hline $\begin{array}{c}\text { Predisposition to the high level } \\
\text { of academic absenteeism }\end{array}$ & $\begin{array}{c}\text { Predisposition to the low level } \\
\text { of academic absenteeism }\end{array}$ \\
\hline Low level of volitional qualities & Diligence, cleanliness and flexibility \\
\hline Independence and self-determination & A motive for gaining knowledge \\
\hline Impulsiveness and low self-control & State-funded education \\
\hline Paying tuition fees by parents & Paying tuition fees by themselves \\
\hline A motive for obtaining a diploma & \\
\hline A motive for mastering the profession & \\
\hline Paying tuition fees & \\
\hline
\end{tabular}

Taking into account the results obtained and interpretations of the study, several recommendations can be formulated for prevention and reduction of academic absenteeism among students. First of all, it is necessary to develop the volitional qualities of a person from the very childhood, since purposefulness, perseverance and responsibility minimizes the likelihood of absenteeism. Psychologists, teachers and parents need to promote the development of self-control, so that a person reaching adulthood would be able to control their own impulsiveness. It is nec- 
essary to increase material support for students at the state level, because the lack of funds in the field of education is the reason why students start working and miss their classes. Material reward for students in order to engage them in scientific work, to write scientific papers would bring benefits, as with the sufficient funding students will be able to fully and properly engage in scientific work and not to think about how and where to earn money for life.

\title{
References
}

1. Гаврилюк Д.Ю. Види електорального абсентеїзму: політологічна теорія. Науковий часопис Національного педагогічного університету імені М.П. Драгоманова. Серія 22: Політичні науки 17 та методика викладання соціально-політичних дисциплін / відп. ред. О.В. Бабкіна. К.: Вид-во НПУ імені М.П. Драгоманова, 2012. Вип. 7. С. 123-128.

2. Мертон Р. Соціальна дія, вписується в соціальний простір. М.: Междунар. ун-т бізнесу та управління, 1996. $556 \mathrm{c.}$

3. Ольшанский Д.В. Массовые настроения переходного времени. Вопросы философии. 1992. № 4. C. 3-15.

4. Cook, L and Etzenne, A. (2010) "Factors Influencing Students" Absenteeism in Primary Schools In Jamaica: Perspectives of Community Members', Caribbean Curriculum (17). P. 34-57.

\section{ПСИХОЛОГІЧНІ ОСОБЛИВОСТІ СТУДЕНТІВ IЗ РІЗНИМ РІВНЕМ АКАДЕМІЧНОГО АБСЕНТЕЇЗМУ}

\author{
Марія-Ольга Сопелюк \\ Львівський національний університет імені Івана Франка, \\ вул. Університетська, 1, м. Львів, Україна, 79000, \\ e-mail: solomaha04@gmail.com
}

Статтю присвячено аналізу академічного абсентеїзму студентів. В емпіричному дослідженні взяв участь 121 респондент, використано комплекс методик: власну анкету, п'ятифакторний тест-опитувальник Р. МакКрае та П. Коста, методику «Вивчення мотивації навчання у виші» T.I. Ільїної, тест-опитувальник особистісної зрілості Ю.З. Гільбуха, методику «Оцінка психологічної атмосфери у колективі» А.Ф. Фідлер та математико-статистичні методи дослідження. Результати дослідження показали, що в 46\% респондентів виявлено середній рівень академічного абсентеїзму, у $29 \%$ - високий рівень, а у $25 \%$ - низький рівень. Виявлено, що мотив отримання знань найбільше переважає в студентів із низьким рівнем академічного абсентеїзму, мотив оволодіння професією та мотив отримання диплому притаманний студентам із високим рівнем академічного абсентеїзму. Результати частотного аналізу свідчать про те, що є відмінності за курсом навчання, формою й оплатою навчання. Зокрема, студенти 3 низьким рівнем навчаються переважно на першому курсі, студенти із середнім рівнем - на першому й третьому курсах, а студенти з високим рівнем академічного абсентеїзму - на третьому курсі. Студенти 3 низьким і середнім рівнем академічного абсентеїзму навчаються на бюджетній формі навчання, а студенти 3 високим рівнем - на платній формі навчання. Що стосується оплати навчання, то студентам із низьким і середнім рівнем академічного абсентеїзму навчання оплачують батьки, а студенти 3 високим рівнем академічного абсентеїзму оплачують навчання самостійно. На основі дослідження створено психологічні портрети студентів. Студенти з низьким рівнем академічного абсентеїзму характеризуються акуратністю, охайністю, експресивністю та пластичністю, тобто досліджувані здатні швидко адаптуватися й пристосуватися до будь-яких змін, робити все чітко, правильно та згідно 3 нормами Студентам із середнім рівнем академічного абсентеїзму притаманна ригідність, вони не схильні швидко адаптуватися до змін. Студентам із високим рівнем академічного абсентеїзму притаманна незалежність, самостійність, низький рівень вольових якостей, низький рівень самоконтролю, відповідальності й настирливості, тобто досліджувані є досить імпульсивними (можливо, саме це сприяє високому рівню абсентеїзму). До того ж студенти з високим рівнем абсентеїзму здебільшого працюють, що також вагомо впливає на відвідуваність закладу вищої освіти.

Ключові слова: абсентеїзм, академічний абсентеїзм, мотиви навчання, психологічний клімат. 